\title{
Ny vin på gamle flasker: Læringsstile i undervisningen på de videregående uddannelser
}

Karen M. Lauridsen, lektor, Institut for Sprog og Erhvervskommunikation samt Learning Styles Lab på Handelshøjskolen, Aarhus Universitet

Ole Lauridsen, lektor og leder af Learning Styles Lab på Handelshøjskolen, Aarhus Universitet

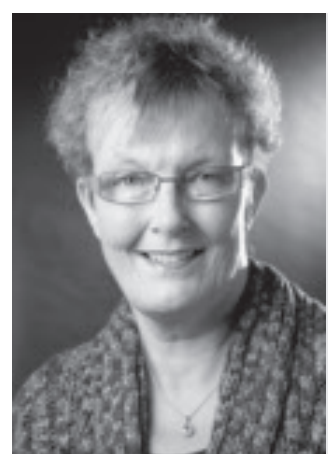

Karen M. Lauridsen er lektor og tilknyttet forskergruppe $\mathrm{Vi}_{\text {- }}$ denskommunikation på Institut for Sprog og Erhvervskommunikation. På Learning Styles Lab arbejder hun med en række forsknings- og formidlingsopgaver og har bl.a. deltaget i udviklingen af kurser $i$ vejledning og anvendelsen af Dunn \& Dunns læringsstilskoncept på forskellige typer af uddannelser samt i appliceringen af konceptet organisationer og virksomheder.

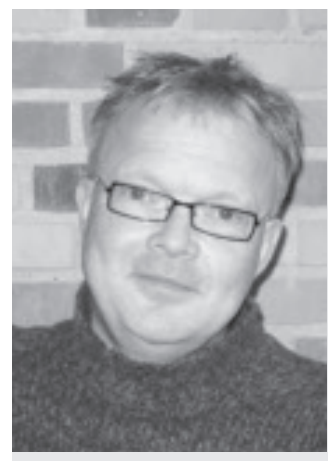

Ole Lauridsen er lektor og leder af Learning Styles Lab samt tilknyttet forskergruppe Videnskommunikation på Institut for Sprog og Erhvervskommunikation. Han har det overordnede ansvar for Learning Styles Labs kursus- og formidlingsopgaver internt på Handelshøjskolen og eksternt i andre uddannelsesinstitutioner, organisationer og virksomheder. Han er endvidere leder af et nyt forskningsprojekt om mulige sammenhænge mellem de studerendes individuelle læringsstilsprofiler, deres demografiske data, adgangsgivende eksamen, karakterniveau og studiegennemførelse. Endelig har han ansvaret for adjunktpædagogikum på Handelshøjskolen og indgår i samarbejde om dette med de øvrige universitetspædagogiske enheder på Aarhus Universitet.

\section{Reviewet artikel}

Denne artikel introducerer Dunn \& Dunns laringsstilsbegreb og den nyere forskning som arbejder med at forklare, hvorfor konceptet har den beviste positive effekt på den enkelte elev/ studerendes laringsudbytte. Herefter gives der eksempler på, hvorledes viden om laeringsstile kan afspejle sig i den konkrete undervisningspraksis.

\section{Introduktion}

Der er i disse år - omsider - for alvor grøde i universitetspædagogikken. Naturligvis har man til alle tider kunnet pege på fremragende undervisere, der har interesseret sig levende for pædagogisk udvikling, men for en stor del af de universitetsansatte har undervisningen når alt kommer til alt ikke været det centrale, og for nogle har den ligefrem været et kors. Dette sidste gælder til en vis grad stadig, men ikke mindst kravet om dokumenteret undervisningskompetence ved fastansættelse i lektor- og professorstillinger og de adjunktpædagogikumsprogrammer, der er blevet udviklet på baggrund af dette krav, har sammen med globaliseringsrapporten (Regeringen, 2006) givet universitetspædagogikken en platform. Pædagogiske centre og laboratorier med fast tilknyttetVIP- og TAP-personale er det synlige bevis herpå, og det samme gælder de udsagn om pædagogikkens betydning, der ses i stort set alle universiteters mission statements.

Handelshøjskolen i Århus etablerede i 2008 et pædagogisk laboratorium, Learning Styles Lab. ${ }^{1}$ Lab'ets omdrejningspunkt er læringsstile efter Dunn \& Dunns teori, konkret i den model der retter sig mod voksne, Building Excellence eller blot BE, udviklet af Rundle \& Dunn og under stadig tilpasning. ${ }^{2}$ 
Dunns og Dunns model er empirisk baseret og tog tilbage i 60'erne sit udgangspunkt i det amerikanske grundskolesystem. Op gennem 90'erne fik andre dele af uddannelsessektoren imidlertid øje for modellen, og omkring årtusindeskiftet fulgte erhvervsliv og organisationer trop, efterhånden som det blev almindelig kendt og accepteret, at læring er meget andet og mere end blot noget, der foregår i en uddannelsessammenhæng. International Learning Styles Network (ILSN), det internationale læringsstilsnetværk, der virker for at udbrede og udforske modellen, består i dag af ca. 30 centre over hele verden. Disse har primært rod i universitetsverdenen, men tæller dog også enkelte skoledistrikter og konsulentvirksomheder. ${ }^{3}$

Af den halve snes læringsstilsteorier man kan tælle i dag (og som har affødt hen ved hundrede enkelte modeller, dvs. visualiseringer med varierende accentueringer eller udbygninger af elementerne i de tilgrundliggende teorier), er Dunn \& Dunns teori den forskningsmæssigt suverænt bedst underbyggede hvad angår den læringsmæssige effekt. Alt $\mathrm{i}$ alt foreligger der således $i$ hundredvis af ph.d.-afhandlinger, bøger og artikler, der dels viser fordelene ved at basere læring på Dunn \& Dunns læringsstilsbegreb, dels dokumenterer, at det virker ved statistisk signifikante forbedringer af elevernes testresultater. En oversigt over denne litteratur findes på det internationale læringsstilsnetværks hjemmeside, og selv om størstedelen heraf har fokus på grundskole- og ungdomsuddannelsesniveauet, herunder fx også forskelle mellem kulturer eller læringsstile som pædagogisk værktøj til elever i specialundervisning, findes der også en del, som dækker videregående uddannelse (se bl.a. Boyle, 2000; Boyle \& Dolle, 2002; Boyle \& Dunn, 1998; Boyle, Russo \& Lefkowitz, 2003; Burke \& Shea Doolan, 2006; Cutolo \& Rochford, 2007; Dunn \& Griggs, 2000; 2003; Giordano \& Rochford, 2005; Ingham \& Boyle, 2006; Reese \& Dunn, 2007-2008; Russo, 2002). En forskningsmæssig opgave for de kommende år er at måle effekten af læringsstile i erhvervs- og organisatorisk sammenhæng.

Mens at'et, altså at Dunn \& Dunns læringsstilsbegreb virker, må siges at være tilstrækkeligt belyst og bevist, er det først gennem de senere år, at det mindst lige så interessante og relevante hvorfor, altså spørgsmålet om hvorfor Dunn \& Dunns læringsstilsbegreb virker, er blevet genstand for forskningen. I forlængelse heraf er formålet med denne artikel først kort at redegøre for Dunn \& Dunns teori, eksemplificeret ved BE-modellen. Herefter introduceres og diskuteres den neurobiologiske/neuropsykologiske forskning, som giver de første væsentlige bidrag til at forstå, hvorfor applikationen af Dunn \& Dunns læringsstilsbegreb har så positiv en effekt på den enkeltes læringsudbytte. Og endelig gives der et eksempel på konkret undervisningspraksis (forelæsning) samt eksempler på de strategier, som de studerende kan anvende for at optimere udbyttet af deres læring. Der fokuseres således i denne del på højere uddannelse, men strategierne kan også anvendes i andre dele af uddannelsessektoren eller på arbejdspladsen.

\section{Læring og læringsstile - en definition}

Læringsstile defineres overordnet som a biological and developmental set of personal characteristics that makes the identical instructional environments, methods, and resources effective for some learners and ineffective for others - eller i Dunn \& Dunns mere almene vendinger som the way each person begins to concentrate on, process, internalize, and retain new and difficult information (Dunn \& Dunn, 1999, s.11).

Som det ses, fokuserer Dunn \& Dunn på information, men med det konstruktivistiske udgangspunkt som typisk karakteriserer moderne (universitets)pædagogik (Illeris, 2000), er mangelen på begrebet viden en udfordring. Definitionen kan dog, uden at der på nogen måde øves vold mod teori og model, ændres, så den bygger på et konstruktivistisk grundlag og har videnopbygning som endemål. Ud fra dette synspunkt bliver læringsstile den eller de metoder, vi anvender, når vi skal koncentrere os om ny og svær information, skal tage denne information ind, bearbejde den til viden, lagre denne viden og bruge denne viden igen (Lauridsen, 2007). Denne definition omfatter en meget stor del af læreprocessen, og heri adskiller den sig markant fra øvrige læringsstilsteoretikeres definitioner, der primært sigter mod indoptaget og/eller bearbejdningen af information.

\section{Building Excellence (BE)}

I BE, altså den konkretisering af Dunn og Dunns model, der er udarbejdet for voksne lærende, opereres der med 28 faktorer eller variable fordelt på 20 elementer samlet i 6 kategorier. De 28 faktorer kan styrke eller svække den enkeltes læring og effektivitet.

De perceptuelle elementer dækker de sansekanaler, som den enkelte lærende foretrækker at anvende, når han/ hun skal optage ny information. Vi har her optag via høresansen (auditiv), via synssansen (visuel) samt via motorisk eller verbal aktivitet (dialog). Det visuelle element er fordelt på to faktorer, nemlig den billedvisuelle, hvor optaget sker via alle typer af billeder eller grafik, og den tekstvisuelle, hvor optaget sker via læsning. Den motoriske aktivitet er ligeledes fordelt på to faktorer: brug af finmotorikken (taktil), det vil sige hænder og fødder, og brug af grovmotorikken (kinæstetisk). For voksne lærende betyder en kinæstetisk styrke ofte involvering i casestudier, problembaseret læring eller rollespil.

At information kan optages til bearbejdning via syns- eller høresansen er ingen nyhed, men mange overser at også kroppen er en væsentlig sansekanal, og under alle omstændigheder kan motoriske aktivite- 


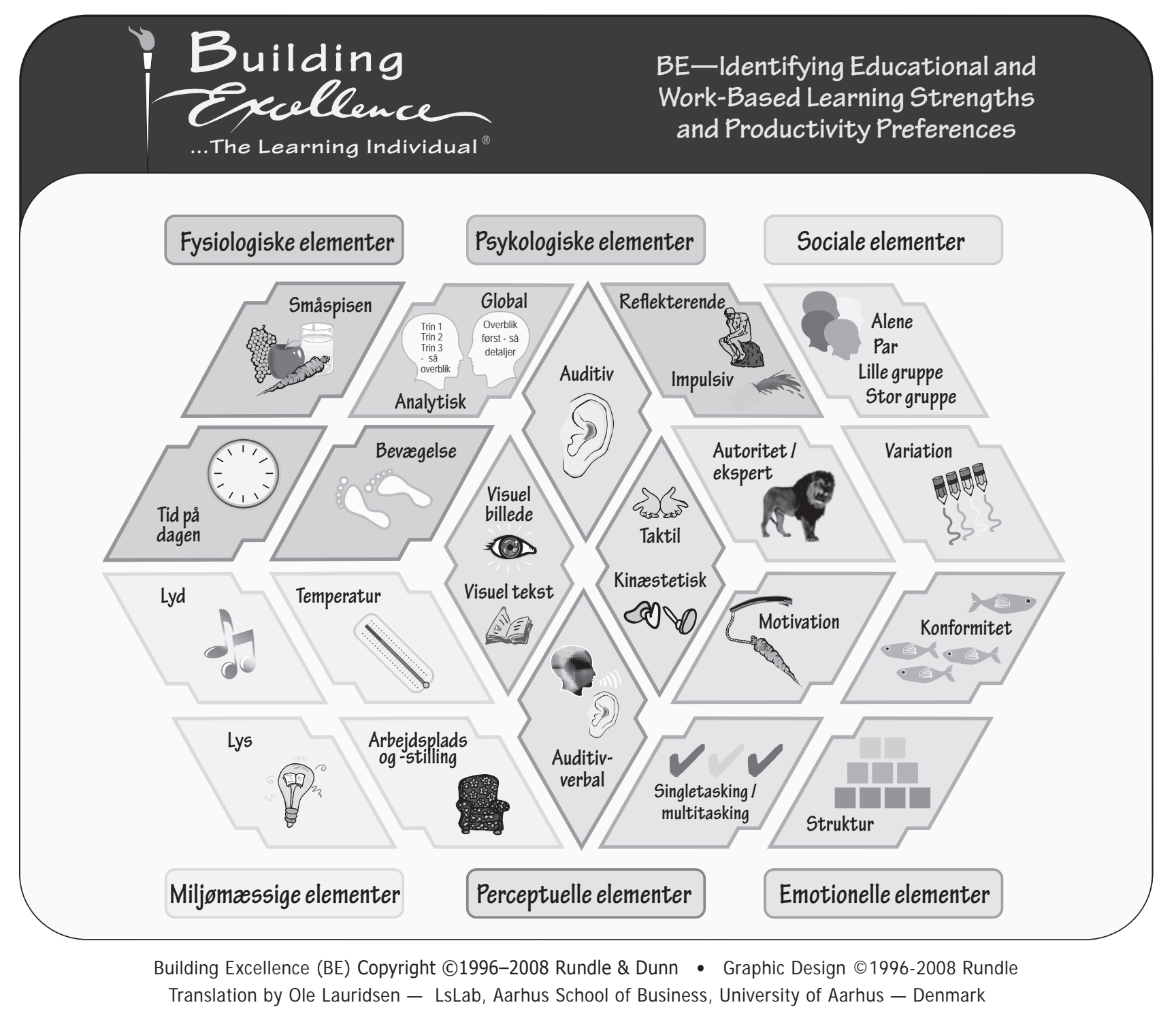

ter støtte den auditive og visuelle sans afgørende. For nogle mennesker fungerer øjne og ører ganske enkelt ikke uden motorisk støtte. Den auditiv-verbale faktor kan umiddelbart synes mindre perceptuel i sin natur. Men at tale, diskutere, memorere højt osv. implicerer for det første lytning, og for det andet er der mange kropsmomenter impliceret $\mathrm{i}$ at tale, fx gestik, mimik og brug af taleorganerne. Den auditiv-verbale faktor samler altså elementer fra såvel det auditive som det taktile og det kinæstetiske.

De psykologiske elementer dækker den lærendes enten globale eller analytiske informationsbearbejdning. I den globale bearbejdning har den enkelte behov for mere overordnede helheder for at kunne konsumere detaljen. I den analytiske bearbejdning bevæger den lærende sig modsat - fra detaljen frem mod det samlede koncept $i$ en logisk skridt for skridt-sekventiering.

Derudover omfatter de psykologiske elementer den reflekterende, altså den mere tilbageholdende, og den impulsive, altså den mere fremfarende adfærd i problemløsning, beslutningstagning og besvarelse af spørgsmål.

De $f y$ siologiske elementer samler den lærendes behov for energiindtag (mad, drikke, rygning), de(t) tidsrum på dagen som den lærende foretrækker at arbejde $\mathrm{i}$ (morgen, midt på dagen, sidst på dagen, aftenen), og endelig den lærendes eventuelle behov for at bevæge sig under læringen.

Blandt de miljømassige elementer finder vi den lærendes behov for lyd (normalt musik) eller stilhed, for mere eller mindre lys og varme og for en traditionel eller en uformel indretning af læringsrummet (det at sidde ved et skrivebord over for det at foretrække en mere komfortabel placering og sidde/ligge i en sofa, seng eller sækkestol).

De emotionelle elementer omfatter den lærendes grad af tilpassethed, altså den lærendes ønske om at følge spillereglerne vs. den lærendes behov for at udfordre status quo (konformitet); den lærendes vedholdenhed (singletasking vs. multitasking); den lærendes behov for at nogen - $\mathrm{i}$ vores sammenhæng i reglen en underviser - strukturerer det stof, der skal behandles (struktur), og endelig den lærendes behov for feedback fra underviseren over for den lærendes ønske om at undgå indblanding i læreprocessen (motivation). Betegnelsen motivation synes uheldig, da den reelt kun dækker di- 
kotomien mellem feedback og ikke feedback, og den afspejler dermed ikke den egentlige motivation, altså al den psykiske energi, vi lægger i læringen (jf. Biggs \& Tang, 2007; Lauridsen, 2007).

I det hele taget er der naturligvis væsentlig flere emotionelle faktorer, der spiller en afgørende rolle for den enkeltes læring, men mange af dem (fx nedtrykthed og depression) kan ikke umiddelbart påvirkes i en læringsproces, der finder sted i samspil med andre ( $\mathrm{fx}$ undervisning). De oplistede følelsesmæssige elementer kan til gengæld umiddelbart håndteres i undervisningssituationen, og tilgodeses de, vil de modvirke stress; dette gælder for så vidt hele paletten af elementer, men de emotionelle er i den forbindelse særlig vigtige.

De sociale elementer indkredser de forskellige personkonstellationer, den lærende foretrækker at arbejde i, nemlig alene, i par, i små grupper, i egentlige teams. Desuden tages der højde for, om den enkelte foretrækker at arbejde under vejledning, og om den lærende foretrækker samme sociale konstellation konstant og/ eller i det hele taget faste rutiner (variation).

Dunn \& Dunns teori foreskriver på basis af et større antal undersøgelser, at man udelukkende skal arbejde med de faktorer, der styrker læringen. Dette skal ses i modsætning til de fleste andre teorier, der anbefaler, at man også arbejder med sine svagere sider for at udvikle det bredest mulige læringspotentiale. Det er således en grundlæggende tankegang hos Dunn \& Dunn, at der ikke findes nogen anden rigtig måde at lære på end den enkeltes helt egen måde at lære på. Alle mennesker skal være opmærksomme på mellem seks (6) og fjorten (14) styrker i deres individuelle læringsstilsprofil, hvilket en række metaundersøgelser godtgør (jf. Dunn og Dunn, 1999, s. 12). Denne profil fastlægges online, for voksnes vedkommende via den såkaldte $\mathrm{BE}$-profilering. ${ }^{4}$ Som resultat heraf făr man et overblik over profilen, der viser den enkeltes læringsstilsmæssige styrker, sammen med en lang række strategier til at omsætte profilen til praksis og dermed udnytte sit læringspotentiale (jf. nedenfor vedr. undervisningspraksis).

\section{Læringsstile og den neurobiologiske/ neuropsykologiske forskning}

Som allerede nævnt er spørgsmålet om, hvorfor anvendelsen af Dunn \& Dunns læringsstilsbegreb virker, blevet taget op i den neurobiologiske/neuropsykologiske forskning. Given (2001) påviser således, at Dunn \& Dunns teorier kobler sig direkte til hjernens fem læringssystemer (det kognitive system (vidensystemet), det emotionelle system (følelsessystemet), det sociale system (systemet for social kontakt og accept), det fysiske system (systemet for kropslig udfoldelse) og det reflektoriske system (systemet for tænkning og eftertanke)). Dermed spiller de ovenfor anførte elementer en rolle for læringen i bredeste forstand, altså omsætningen af information til viden med de ændringer, dette betyder for den enkeltes syn på sig selv og sin omverden (Given, 2001; Lauridsen, 2007).

Thies et al. (2001) og Thies (2003) omgrupperer læringsstilsmodellens elementer og indplacerer dem $i$ tre grupper svarende til de tre hjernefunktioner, der er aldeles centrale for al læring (jf. også Fredens, 2004): Arousalfunktionen varetager opmærksomhed, parathed, og homøostase; ${ }^{5}$ eksekutivfunktionen varetager motivation, initiation, organisation, overvågning og kontrol; og processeringsfunktionen varetager informationsbearbejdning, læringsmetoder, kognitiv aktivitet, lagring af viden og brug af viden. Elementerne i BE (eller de øvrige Dunn \& Dunn modeller) kan umiddelbart fordeles påThies' tre funktioner, idet arousalfunktionen dækker lyd, temperatur, lys, indretning, småspisen og tid på dagen; eksekutivfunktionen dækker motivation ( \pm feedback), impulsiv/reflektiv, bevægelse, struktur, konformitet, vedholdenhed og indretning; og endelig dækker processeringsfunktionen informationsbearbejdningen (analytisk/global), perceptionen og alle sociale elementer. Bemærk, at elementet indretning spiller en rolle inden for to af de tre funktioner, nemlig både i arousal- og eksekutivfunktionen.

Både Givens og Thies' forskning cementerer læringsstilenes betydning for lærende $\mathrm{i}$ alle aldre, på alle niveauer og i alle sammenhænge, og selvom Thies understreger, at der for hans forsknings vedkommende foreløbig udelukkende er tale om en hypotese, virker hans arbejder aldeles overbevisende, da de baserer sig på velovervejede vurderinger af fMRI-scanninger. ${ }^{6}$ Den neurobiologiske/neuropsykologiske forskning synes med andre ord umiddelbart at passe sammen med Dunn \& Dunns empirisk baserede pædagogiskdidaktiske udgangspunkt, hvilket må siges at understøtte begge parters resultater.

Dunn \& Dunns teori og modeller kritiseres i akademiske kredse ofte for at være for simple og banale. Denne kritik er efter vores begreber helt forfejlet. Der arbejdes unægtelig for en stor dels vedkommende med velkendte forhold, som de fleste kan nikke genkendende til også uden at kende til Dunn \& Dunn, men det i sig selv kan ikke med nogen rimelighed være et angrebspunkt. Skal alt være stærkt abstrakt for at kunne finde accept i den akademiske verden? Netop modellens enkelhed er dens styrke: Alle kan forstå hvad den drejer sig om, og alle - både studerende og undervisere - kan håndtere den og omsætte den til praksis. Den skaber et fælles læringssprog, og i det øjeblik man kender den og bruger den, fremmer den gensidig respekt og tolerance.

\section{Læringsstile i den konkrete undervisningspraksis}

Det er klart, at undervisningen og underviseren ikke kan tilgodese de mange studerendes mange stærkt forskellige profiler, og den praktiske anvendelse er på 
mange måder også den enkelte studerendes personlige anliggende og ansvar. Dog er der en række elementer, som langt de fleste mennesker (ca. $70 \%$ ) har repræsenteret i deres profil (Dunn \& Dunn, 1978). Det drejer sig om de perceptuelle elementer, informationsbearbejdningen, tid på dagen, lys og indretning, og her kan underviserne så afgjort yde deres. Materialer kan tilrettelægges, så de tager hensyn til de forskellige sanser, og informationer kan gives, så både globale og analytiske studerende får dem præsenteret på den mest hensigtsmæssige måde; undervisning og vejledning på ydertidspunkter kan undgås $i$ videst muligt omfang (eller afstemmes for vejledningens vedkommende efter de studerendes behov), og en lidt alternativ måde at sidde på kan accepteres og ikke affærdiges som et klart tegn på manglende koncentration eller desinteresse. Desuden kan adskillige fag tilrettelægges kinæstetisk ved inddragelse af kroppen (diverse kropsbaserede indlæringsspil) eller - og vigtigere i en voksen-kontekst ved at benytte cases, rollespil og andre metoder, der involverer den lærende som person.

Lad os prøve at udfolde disse tanker i en mere konkret undervisningssammenhæng og som eksempel tage forelæsningen. I sin klassiske udgave understøtter denne undervisningsform ikke læringen i særlig høj grad, passiverende som den er. Imidlertid er den en nødvendighed i dagens videregående uddannelser, og for mange undervisere behagelig, fordi afviklingen er så meget mere håndterlig end studenteraktiverende undervisningsformer; man skal i øvrigt heller ikke overse, at det bekommer mange studerende vel ikke at blive inddraget og skulle stå til regnskab for viden, forståelse og meninger - eller mangel på samme.

En forelæsning helt uden visuel støtte $i$ form af overhead eller en PowerPoint-præsentation henvender sig naturligvis i første række til de auditivt lærende, og de udgør faktisk et mindretal; under $30 \%$ af en voksen befolkning er auditive, og især mænd er meget lidt auditive (Dunn \& Griggs, 1998; Lauridsen, 2007). Samtidig er forelæsninger, i pagt med den vestlige tradition, i reglen stærkt analytisk opbyggede, og dermed rammer de ikke den temmelig store gruppe af globale, der er afhængige af helheder for at kunne forstå detaljen. I et overordnet perspektiv er $55 \%$ voksne globale, $28 \%$ analytiske og de resterende $17 \%$ integrerede, dvs. de kan bearbejde information på både den analytiske og den globale måde. Helt foreløbige undersøgelser af Handelshøjskolens optag i 2008 viser imidlertid, at der i studentermassen er væsentlig færre globale end generelt, men stadig er der en ikke ganske ubetydelig gruppe af globale studerende, der naturligvis bør tilgodeses; i et forestående forskningsarbejde vil disse forhold blive behandlet nærmere.

De her nævnte forhold har væsentlige implikationer for tilrettelæggelsen af forelæsningen. For det første er det afgørende, at alle sanser adresseres: at der tales til forsamlingen (auditivt), at der arbejdes med billede og tekst (visuelt), at de studerende făr mulighed for at inddrage motorikken (taktilt/kinæstetisk), og at de selv får lejlighed til at italesætte informationsoptaget (auditiv-verbalt). Det auditive er jo et basiselement i forelæsningsdiskursen, og efterhånden benytter flertallet af forelæsere PowerPoint-præsentationer, der i princippet understøtter det visuelle. Mange PowerPointpræsentationer er imidlertid så dårligt opbyggede, at de snarere hæmmer end styrker læringen, og meget ofte interagerer forelæseren mindre hensigtsmæssigt med sin præsentation, idet han eller hun tenderer til slavisk at læse, hvad der står på skærmen; dertil kommer, at mange ikke stiller handouts til rådighed for de studerende for forelæsningen. En velkomponeret PowerPoint-præsentation skal have slides, hvis samlede informationsmængde ikke karambolerer med Millers $7 \pm 2$ regel: arbejdshukommelsen kan maksimalt bearbejde ni (9) informationsenheder ad gangen og understimuleres ved færre end fem (5) (Miller, 1956). Der bør arbejdes med regulær tekst - ikke stikord, og de enkelte slides skal i videst muligt omfang forsynes med underbyggende billedmateriale; Blokzijl \& Andeweg (2006) har således vist at studerende husker op til $50 \%$ mere af det gennemgåede stof, når disse ting tages $i$ betragtning.

Handoutet er naturligvis også en støtte for den visuelle og for den taktile studerende, der kan tage noter, bladre rundt osv., men samtidig gavner det i samspil med skærmpræsentationen og forelæserens "speak « informationsoptaget for både analytiske og globale. Generelt bør man tage afsæt i den analytiske tilgang - dels er der som antydet antagelig flere analytiske end globale på i det mindste Handelshøjskolens uddannelser, dels viser erfaringen, at man kobler de analytiske af, hvis man starter med for overordnede udblik. Rent teknisk kan man tilgodese den analytiske informationsbearbejdning ved i PowerPoint-præsentationen at arbejde med animationer, hvorefter informationsenhederne (bullets) præsenterer en for en. Den analytiske har behov for at konfirmere den helhedsforståelse, han eller hun har fået, og det kan naturligvis ske ved at betragte den fulde skærm. Imidlertid haster forelæseren ofte videre, og det er derfor en stor fordel for den analytiske studerende at have sit handout foran sig og på basis af det cementere overblikket. Omvendt vil den globale have det meget svært med ikke at kunne kaste et blik på helheden før detaljerne præsenteres; for dem er bullet-for-bullet-fremgangsmåden alt andet end hensigtsmæssig, men her kommer så igen handoutet ind, idet det kan forsyne den globale med et hurtigt overblik. Bemærk at der ikke skal nærlæses - hverken blandt analytiske eller blandt globale studerende - der er alene tale om et hurtigt kig $\mathrm{i}$ handoutet for begge typer. Ud over dette er det centralt, at forelæseren konstant skifter mellem korte logiske fremadskridende fremstillinger af hensyn til de analytiske, og mere helhedsprægede, mere malende fremstillinger af hensyn til de globale. 
Udformningen af PowerPoint-præsentationer behandles mere indgående hos Lauridsen (2006b).

Forelæsninger er jo i hovedsagen envejskommunikation. Ganske vist åbner mange forelæsere mulighed for, at der kan stilles spørgsmål, men derved aktiveres kun et fåtal. En måde at aktivere alle studerende på er med passende mellemrum at indlægge en såkaldt nabohøring eller »think-pair-share«-aktivitet: Man beder de studerende hver især tænke på $\mathrm{fx}$ to for dem frapperende ting $\mathrm{i}$ det, de har hørt så vidt (1 minut); dernæst beder man dem "dele« det de har tænkt på med sidemanden (2-3 minutter). Dette afføder generelt en stor aktivitet $\mathrm{i}$ auditoriet, og herved tilgodeses de studerendes udtalte auditivt-verbale behov. Bemærk at man ikke debriefer, ikke spørger til hvad der er blevet diskuteret; kun italesættelsen og den læreproces, der igangsæettes, er central. Man kan herudover også med fordel arbejde med korte timeouts under forelæsningen, 10-15 sekunders pause, hvor forelæseren går på standby; dette giver alle mulighed for at få ro i tankestrømmen, og samtidig kan de studerende udveksle korte kommentarer indbyrdes.

Herudover er den egentlige udnyttelse af styrkerne som nævnt op til den lærende; dog skal det fastholdes at en undervisers viden om læringsstile og det udslag forskellighederne giver, vil kunne forklare og nedtone mange af de problemer han eller hun møder i sin undervisningspraksis. Erkendelsen af, at det ene eller det andet løb af sporet, ikke nødvendigvis på grund af underviseren selv, men snarere på grund af særlige behov blandt de studerende, er en god ballast.

\section{Strategier til at udnytte den enkeltes styrker}

Ligesom modellen er enkel, er de strategier, som præsenteres $i$ forbindelse med BE-profileringen og i litteraturen i det hele taget, for så vidt enkle, og de indbyder til yderligere individuel eksperimenteren. Der skal her ikke gås i dybden med strategierne, men kun gives et par eksempler.Yderligere herom findes bl.a. i Lauridsen (2007).

\section{De auditive studerende}

De auditive studerende (de studerende som har høresansen som deres stærkeste perceptuelle præference) lærer og husker bedst, når ny information går gennem øret. De kan medbringe en mp3-spiller, pc eller mobiltelefon til undervisning og projekt- eller vejledningsmøder og optage alt, hvad der bliver sagt. Mange undervisere og mødedeltagere vil muligvis stejle over dette, men når man forklarer hvorfor, altså henviser til læringsstile, vil de fleste acceptere det uden videre.

Hvis man har lydkort og højttalere i sin computer (og det har vel de fleste), så kan man bruge programmer som Microsofts Document Imaging ${ }^{7}$ og AdgangForAlle ${ }^{8}$ til oplæsning af tekst fra skærmen - lærebøger, rappor- ter, e-mails osv. Hvis man hører teksterne eller læser dem, samtidig med at man lytter til oplæsningen, kan høresansen støtte indlæringen ganske betydeligt for den auditivt stærke studerende.

I forlængelse heraf kan man anbefale de auditive studerende at læse skrevet materiale op for sig selv og evt. optage det på mp3-spiller, pc eller mobiltelefon. De kan også indtale noter og kommentarer til en tekst, som de læser, i stedet for at skrive dem ned. De auditive studerende vil endvidere have glæde af at tale højt med sig selv, når de forbereder sig, prøver at huske indhold fra undervisning eller møder osv. De kan optage det, de siger, og høre det igen. De kan fx afspille deres optagelser når de forbereder sig, men fx også mens de kører bil, eller mens de arbejder med noget praktisk: strikker, tegner, maler, graver i haven, eller løber en tur. Den auditive vil også foretrække at fă information via telefon og voicemail $i$ stedet for sms eller mail. De studerende med en stærk auditiv præference kan have brug for at bede folk om at sætte tempoet ned, hvis de taler for hurtigt, og om at tale tydeligere, hvis de mumler.

E-learning vil næppe være godt for den stærkt auditive studerende, medmindre der er indlagt muligheder for at bruge synkron mundtlig kommunikation ( $\mathrm{fx}$ skype) eller lydfiler. De auditive studerende kan selv råde bod på disse mangler ved at bruge Document Imaging og AdgangForAlle.

\section{Den analytiske informationsbearbejdning}

De analytiske studerende bearbejder information i logiske sekvenser i en ordnet fremadskridende proces frem mod det samlede koncept. De har derfor glæde af altid at gå skridtvis frem, når de kaster sig over nyt stof eller nye problemer. De skal ikke bladre rundt $\mathrm{i}$ omdelt materiale eller lærebøger, men tage det forfra afsnit for afsnit.

De analytiske studerende har også behov for at organisere deres tid og deres arbejde. De kan derfor have glæde af aktivitetsskemaer, $\mathrm{fx}$ en time-manager, af at skrive arbejdsopgaver på lister med logisk nummerering $(1-1.1-1.1 .1-1.2-2$ / kl. 8-9, kl. 9-10 osv.) og af at udarbejde hierarkisk opbyggede mindmaps.

De har brug for at satse på ræsonnement og logik, på at dyrke dette, men ikke overdrive det. De må ikke lade andres (de globales) idéstrøm bremse deres behov for detaljer, men bør sørge for at arbejde for en fornuftig balance. På samme måde bør de analytiske studerende også søge beviser og facts, men samtidig også være åbne over for mere flagrende indfald, der ofte fører en diskussion eller en udredning videre $i$ en overraskende retning. Det nye spor kan de så tage fat på ud fra deres analytiske overvejelser.

Det er en udfordring for de analytiske studerende at deres analytiske præferencer ikke må tage overhånd så at helheden drukner i detaljer. De bør derfor bryde 
komplekse ideer op i detaljer, som de så derefter ordner $i$ en logisk rækkefølge; igen kan hierarkisk organiserede mindmaps være til stor hjælp. Hvis de analytiske studerende vil brainstorme, er det en god ide at bruge kartotekskort eller sticky-notes. Det giver dem mulighed for at gennemgå detaljerne på materialet og derefter sortere og ordne dem efter logiske principper (Lauridsen, 2007).

\section{Afrunding}

Efter en introduktion til Dunn \& Dunns læringsstilsbegreb har vi både givet eksempler på, hvordan forelæseren med fordel kan indtænke læringsstile i afviklingen af forelæsningen, og på, hvorledes den enkelte studerende kan udnytte sine styrker i læreprocessen og dermed øge sit læringspotentiale. Med udgangspunkt $i$ såvel egne erfaringer som den foreliggende litteratur om appliceringen af læringsstilsbegrebet på videregående uddannelser er der derfor grundlag for at konkludere, at læringsstile efter Dunn \& Dunn er et godt redskab både for den enkelte studerende og for underviserne på de videregående uddannelser.

Som vi endvidere har godtgjort, har Dunn \& Dunns grundlæggende teori og metoder været genstand for omfattende forskning der viser at de virker. Det interessante er nu at se på, hvorfor det forholder sig sådan. En forklaring er samspillet med den neurobiologiske / neuropsykologiske forskning, men der er sandsynligvis også andre forklaringer, som empiriske studier af korrelationen mellem de studerendes individuelle læringsstilsprofil, demografiske faktorer og andre faktorer i læringsprocessen vil kunne afdække.

\section{Litteratur}

Biggs, J. \& Tang, C. (2007). Teaching for Quality Learning at University, Maidenhead, Berkshire: Open University Press, McGraw Hill.

Blokzijl, W. \& B. Andeweg (2006). The effectiveness of visualisations compared to text slides in lectures, paper presented at the SEFI $34^{\text {th }}$ Annual Conference. 28.6.-1.7.2006. Sweden: Uppsala.

Boyle, R.A. (2000). Bringing learning-style instructional strategies to law school:You be the judge! I: R. Dunn \& S. Griggs. Practical approaches to using learning styles in higher education (pp. 155-165). Westport, Conn.: Bergin \& Garvey.

Boyle, R.A. \& L. Dolle (2002). Providing structure to law students - Introducing the programmed learning sequence as an instructional tool. Legal Writing: The Journal of the Legal Writing Institute, 8, 59-146

Boyle, R.A. \& Dunn, R. (1998). Teaching law students through individual learning styles. Albany Law Review, 62(1), 213-255

Boyle, R.A., Russo, K. \& Lefkowitz, R.F. (2003). Presenting a new instructional tool for teaching law-related courses: A Contract Activity Package for motivated and independent learners. Gonzaga Law Review, 38(1), 1-31.

Burke, K. \& Shea Doolan, L.J. (2006). What professors need to know about their students' learning styles: How can educators help to produce the best learners? I: R. Sims \& S. Sims (eds.). Learning styles and learning: $A$ key to meeting the accountability demands in education (pp. 163-174). Hauppauge, NY: Nova Science Publishers.
Cutolo, A. \& Rochford, R.A. (2007). An analysis of freshmen learning styles and their relationship to academic achievement. College Quarterly, 10(2), 1-17. http://www.senecac.on.ca/ quarterly/2007-vol10-num02-spring/cutolo_rochford.html

Dunn, R. \& Dunn, K. (1978). Teaching students through their individual learning styles: a practical approach. Reston, Va.: Reston Pub. Co.

Dunn, R. \& Dunn, K. (1999). The Complete Guide to the Learning Styles Inservice System. Needham Heights, MA:Allyn \& Bacon.

Dunn, R. \& Griggs, S. (1998). Multiculturalism and Learning Style. Westport, Conn.: Praeger Publishers.

Dunn, R. \& Griggs, S. (2000). Practical approaches to using learning styles in higher education. Westport, Conn.: Bergin \& Garvey.

Dunn, R. \& Griggs, S. (red.) (2003). Synthesis of the Dunn and Dunn Learning-Style Model Research. Who, What, When, Where, and So What? New York: St. John's University.

Fredens, K. (2004). Mennesket $i$ hjernen - en grundbog i neuropadagogik. Århus: Systime.

Giordano, J.L. \& Rochford, R. (2005). Understanding business majors' learning styles. The Community College Enterprise, 11(2), 21-39.

Given, B. (2001). The brain's natural learning systems. Alexandria,VA: Association for Supervision and Curriculum Development.

Illeris, K. (2000). Laring - aktuel laringsteori i spandingsfeltet mellem Piaget, Freud og Marx. Roskilde: Roskilde Universitetsforlag

Ingham, J. \& Boyle, R.A. (2006). Generation X in law school: How these law students are different from those who teach them. Journal of Legal Education, 56.

Kastberg, P. et al. (2007). Personligt Knowledge Management. København: Samfundslitteratur.

Lauridsen, K.M. (2008). Hjernen er ikke en krukke der skal fyldes, men en ild der skal tændes. Om vejledning og vejledningskurser på Handelshøjskolen, Aarhus Universitet. Dansk Universitetspeedagogisk Tidsskrift, 6, 20-24.

Lauridsen, O. (2006a). Læringsstile og personligt knowledge management. I: P. Andersen (red.). Laringens og tonkningens stil (s. 175-186). København: Billesø og Baltzer.

Lauridsen, O. (2006b). Laringsstile og PowerPoint. En ny spandende indgangsvinkel, Microsoft Danmark. Kan downloades fra www. asb.dk/lslab.

Lauridsen, O. (2007). Fokus på laring - om lacingsstile i dagligdagen, professionelt og privat. København: Akademisk Forlag.

Miller, G. A. (1956). The magical number seven, plus or minus two: Some limits on our capacity for processing information. Psychological Review, 63, 81-97.

Reese,V. \& Dunn, R. (2007-2008). Learning-style preferences of a diverse freshman population in a large, metropolitan university by gender and GPA.Journal of College Student Retention. Research, Theory \& Practice, 9(1), 95-112.

Regeringen (2006). Fremgang, fornyelse og tryghed. Danmark $i$ den globale økonomi, Albertslund: Schultz Information.

Russo, K. (2002). Teaching law students: An innovative approach. Academic Exchange Quarterly, 6(4), 151-159.

Thies, A. (2003). Implication of Neuroscience and Neuropsychology for the Dunn and Dunn Learning Style Theory. I: R. Dunn \& S. Griggs (red.). Synthesis of the Dunn and Dunn Learning-Style Model Research. Who, What, When, Where, and So What? (pp. 49-53). New York: St. John's University.

Thies, A. Dunn, R. \& Honigsfeld, A. (2001). Synthesis of the Dunn and Dunn learning-style model research: analysis, New York: St John's University, Center for the Study of Learning and Teaching Styles.

\section{Noter}

1 www.asb.dk/LsLab. Se evt. også Lauridsen (2008).

2 Denne information kan gives på baggrund af forfatternes tætte samarbejde med Susan Rundle der administrerer og vedligeholder BE. BE 2000 Research Manual kan downloades fra 
Learning Styles Labs hjemmeside på http://www.asb.dk/fileexplorer $/$ fetchfile.aspx?file $=7783$.

3 En samlet oversigt over netværkets centre findes på www. learningstyles.net

4 Profileringerne for såvel voksne (Building Excellence) som børn tages online på www.learningstyles.net. Flere af profileringsværktøjerne er oversat til dansk; dette gælder også for BE. efter at opnå og opretholde en konstant ligevægt i forholdet til sine omgivelser ved til stadighed at tilpasse sig (Illeris 2000). I læringssammenhæng er der specielt tale om trangen til eller driften mod at dække et vidensbehov.

6 fMRI: (= funktionel magnetisk resonanstomografi) er en ny scanningsmetode, der gør det muligt at afdække processer, der ligger dybt i hjernen; ældre typer af hjernescanninger måler heroverfor udelukkende på hjernens overflade.

7 Document Imaging er en del af Office-pakken.

8 www.adgangforalle.dk 